HNF-18944

Revision 0

\title{
Hanford Beryllium Steering Group Charter
}

Prepared for the U.S. Department of Energy

Assistant Secretary for Environmental Management

\section{Fluor Hanford}

P.O. Box 1000

Richland, Washington

Contractor for the U.S. Department of Energy

Contractor for the U.S. Department of Energy
Richland Operations Office under Contract BE-AC06-96RL13200

Approved for Public Release

(Upon receipt of Clearance approval)

Further Dissemination Unlimited 
HNF-18944

Revision 0

\section{Hanford Beryllium Steering Group Charter}

E.R. Hewitt, Fluor Hanford, Inc.

December 2003

Prepared for the U.S. Department of Energy

Assistant Secretary for Environmental Management

\section{Fluor Hanford}

P.O. Box 1000

Richland, Washington

Contractor for the U.S. Department of Energy
Richland Operations Office under Contract DE-AC06-96RL13200

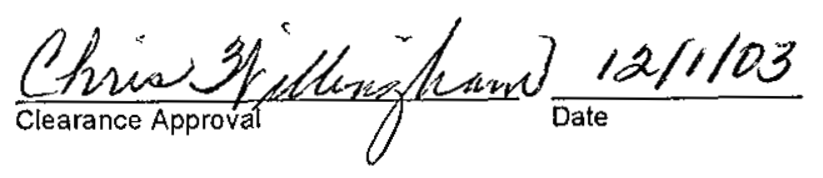

N/A

Release Approval (stamp)

Approved for Public Release

(Upon receipt of Clearance approval)

Further Dissemination Unlimited 
HNF-18944

Revision 0

\begin{tabular}{|l|l|}
\hline \multicolumn{2}{|c|}{ For use with Technical Documents (when appropriate) } \\
\hline EDC- & FMP- \\
\hline EDT- & ECN- \\
\hline Project No.: & Division: \\
\hline Document Type: RPT & Page Count: $\mathrm{l} l$ \\
\hline
\end{tabular}

\begin{tabular}{|l|l|l|l|}
\hline \multicolumn{3}{|c|}{ For use with Speeches, Articles, or Presentations (when appropriate) } \\
\hline Abstract & Summary & Full Paper & Visual Aid \\
\hline Conference Name: & & \\
\hline Conference Date: & & \\
\hline Conference Location: & \\
\hline Conference Sponsor: & \\
\hline Published in: & \\
\hline Publication Date: & \\
\hline
\end{tabular}

\section{LEGAL DISCLAIMER}

This report was prepared as an account of work sponsored by an agency of the United States Government. Neither the United States Government nor any agency thereof, nor any of their employees, nor any of their contractors, subcontractors or their employees, makes any warranty, express or implied, or assumes any legal liability or responsibility for the accuracy, completeness, or any third party's use or the results of such use of any information, apparatus, product, or process disclosed, or represents that its use would not infringe privately owned rights. Reference herein to any specific commercial product, process, or service by trade name, trademark, manufacturer, or otherwise, does not necessarily constitute or imply its endorsement, recommendation, or favoring by the United States Government or any agency thereof or its contractors or subcontractors. The views and opinions of authors expressed herein do not necessarily state or reflect those of the United States Government or any agency thereof.

Scientific or technical information is available to U.S. Government and U.S. Government contractor personnel through the Office of Scientific and Technical information (OSTI). It is available to others through the National Technical Information Service (NTIS).

This report has been reproduced from the best available copy. 


\section{Hanford Beryllium Steering Group \\ Charter}

\subsection{PURPOSE}

The purpose of the Beryllium Steering Group (BSG) is to 1) provide a forum for discussion of beryllium issues and concerns among Hanford prime contractors and DOE; 2) review proposed changes in prime contractor Chronic Beryllium Disease Prevention Programs (CBDPP) to determine if these changes will result in significant impacts to other contractors and their employees; 3) review proposed changes to Beryllium Hanford Facilities List prior to updating of this list.

\subsection{MEMBERSHIP}

Membership will consist of:

- a company-appointed representative or alternate for each prime contractor;

- DOE representatives as determined by DOE;

- a representative from the Beryllium Awareness Group.

These representatives will be primarily from the Occupational Safety and Health field, though this is not a requirement. Membership is not closed, and members may bring other individuals from their companies as they deem appropriate.

\subsection{ORGANIZATION}

The BSG is intended to be a forum for discussion and questions relating to berylliumrelated activities at Hanford. DOE, its Contractors, and the BAG representative will have opportunities to participate in discussions and share perspectives. The BSG will not be a voting organization, and will not have authority to approve or reject the information presented. Rather, it will act as a "sounding board" for contractors to determine if the proposed actions are reasonable and whether they create problems for other contractors. The intent will be to provide constructive feedback to improve contractor CBDPP while pointing out areas of potential problems. The comments and suggestions made by BSG members will be only recommendations, and the contractors will not be bound by them.

\subsection{GROUP OPERATION}

4.1 The members of the group will include a chairperson and a recording secretary. These positions will be voluntary. The chairperson will be responsible for conducting regularly scheduled meetings and will be the group spokesperson. The recording secretary will maintain the membership roster, keep minutes of discussion topics, issues of concern, and progression of issue resolution to final disposition. The recording secretary will keep and transmit minutes of the meetings to the chair for approval and distribution.

4.2 The group will establish subcommittees from time to time to complete various tasks agreed to by the members. Each subcommittee will have a chairperson who is responsible for conducting meetings, completing assigned tasks and reporting to the $\mathrm{BSG}$. 


\section{Hanford Beryllium Steering Group \\ Charter}

- 4.3 The group shall meet monthly, or as otherwise agreed to by the members. An agenda will be published and distributed in advance of or at the start of each meeting.

4.4 The BSG will establish by-laws as needed.

4.5 When new information is obtained about facilities on the Beryllium Facilities List, the prime contractor responsible for the facilities will review the current Facility Fact Sheet and Facility List to determine if any updates are needed. If an update is needed, draft copies of each of the affected documents will be prepared and brought to the next meeting for discussion. After review by the Group, the information will be used to update the appropriate Sheets or List, which are maintained on the Hanford Beryllium Web Site by FH. For facilities where no new information is obtained, each prime contractor is expected to review the current facility information annually and make changes as needed using the above process. Attachment 1 provides additional information relating to specific items to be addressed during CBDPP updates.

4.6 When a prime contractor decides to make changes in their Chronic Beryllium Disease Prevention Program implementing document that might impact other prime contractors, the proposed changes will be brought to the next Group meeting for review and discussion prior to implementation. This is to ensure that other contractors are informed of the changes before they are implemented and have an opportunity to discuss impacts on their operations.

\subsection{INITIATIVES/ACTIONS}

BSG initiatives/actions will be discussed by the Group and, where possible, a consensus will be reached among the prime contractors concerning the best way to proceed. However, no votes will be taken, and any decisions made by the Group will be in the form of recommendations, and will not be binding on any contractor. With regards to proposed changes of a contactor CBDPP, the DOE head contracting authority (HCA) for each contract is ultimately the regulator and only binding authority. A contractor may submit to their DOE HCA a revised CBDPP with whatever proposed changes they deem necessary, with or without prior discussion at the BSG, with or without acceptance of it by the other contractors. However, the DOE offices will work together to ensure that the proposed changes are compatible and/or consistent with the key implementing features of CBDPPs at Hanford. This will include work with the BSG and contractors to verify that the impacts and compatibility of proposed changes have been considered. Bringing proposed changes to the BSG should thus accelerate this process, ensure compatibility with existing contractor beryllium programs and minimize the potential for conflicts. The net effect should be to have a smoother, faster DOE review and approval process.

\subsection{Charter Review}

The Beryllium Steering Group Charter will be reviewed by the BSG at least annually during a regular BSG meeting and updated as needed. 


\section{Hanford Beryllium Steering Group \\ Charter}

\section{Attachment 1}

From: $\quad$ Jackson, David L (Dave)

Sent: $\quad$ Tuesday, September 02, 2003 10:24 AM

To: $\quad$ Austin, Becky A; Gergely, Dale E; Caldwell, Cynthia L; Enge, Roby D;

Eberlein, Susan J; Coleman, Sheldon R; Price, Dale N

Cc: $\quad$ Eizaguirre, Joe; Shoop, Doug S; Hewitt, Elton R

Subject: $\quad$ Approved minutes to Contractor Meeting on CBDPP Path Forward

With no further changes by the comments collected last week, these are now the official meeting minutes our meeting on CBDPP. I have tasked the Beryllium Steering Group to begin actions.

\section{Meeting by Site Contractors and DOE to Discuss Future of CBDPP}

Representatives from the Hanford site contractors met with DOE-RL to discuss the future of a single site CBDPP. It was agreed that the need for a single CBDPP could go away now that there are/will be three different DOE oversight structures on the site (RL, ORP, and Office of Science). It was also understood that due to these events and contractual changes that $\mathrm{FH}$ is released from the obligation to coordinate the submittals of a single CBDPP.

The path forward concluded by the group is to publish the existing and approved CBDPP, because it has recently been completed and approved, but it will not be maintained or modified in the future. To maintain a level of Hanford consistency in the contractor's beryllium programs, the group decided that the Beryllium Steering Group would be that mechanism to openly discuss and present individual contractor activities, actions or policies that may deviate from the existing CBDPP. The Beryllium Steering Group will be tasked with defining subjects and areas in the CBDPP that are necessary for the contractors to maintain consistent practice, such as :

- Definitions

- Postings

- Limits of Detection

- Training

- Medical Surveillance

Changes to or migration away from these areas of consistency, will be the focus of discussion and decision of the Be Steering Group. These areas will be defined in documents that provide the charter or scope of the Be Steering Group, or result in a MOA if necessary to guide the Hanford contractors in a consistent implementation of the Beryllium program.

Dave

David L.. Jackson, Director Occupational Safety \& Health

Fluor Hanford, Inc.

(509)373-1289 